\title{
Perception of Teacher Trainees at The Federal University Oye Ekti, Nigeria Towards Teaching Profession
}

\author{
Bolupe A. Awe* and B. N. Balogun \\ Department of Educational Management and Business Studies, Faculty of Education, Federal \\ University, Oye Ekiti, Nigeria
}

\section{ARTICLE INFO}

\begin{tabular}{l}
\hline Keywords: \\
Perception \\
Teaching \\
Undergraduate \\
Education \\
Students
\end{tabular}

\begin{abstract}
The study investigated the perception of undergraduate education students at Federal University Oye Ekiti, Nigeria towards teaching profession. Descriptive research design of the survey type was adopted for the study. An instrument adapted from Alkhateeb (2013) and tagged Students' Attitude on Teaching Profession (SATPQ) was used to obtain data for the study. Simple random sampling technique was used to select the sample comprising of 187 undergraduate education students at 100 and 200 level. One research question was raised while four research hypotheses were generated for the study. The hypotheses were tested at 0.05 level of significance. The outcome of the study revealed that undergraduate education students at the Federal University Oye Ekiti had positive attitude towards teaching profession. The study revealed that there was no significant difference in the perception of undergraduate education students at the Federal University Oye Ekiti towards teaching profession based on gender, level of entry, age and entry qualification. Based on the findings of the study it was recommended that undergraduate education students should be provided with necessary incentive to sustain their positive perception towards teaching profession while government should formulate a policy that could change societal perception on teaching profession.
\end{abstract}

\section{Introduction}

The unique position of teachers in educational system underscores their importance in the realization of educational aims and objectives of any nation. This is premised on the crucial roles they play in instructional delivery. In Nigeria, recognition of teachers is articulated in the National Policy on Education where it is stated that the quality of education in any nation cannot rise above the quality of its teachers, (FRN, 2004, p.3). This is buttressed by Okobia (2011) who observed that even with the best educational policy, design and the expenditure of colossal sum of money for education, the ultimate realization of any aims of education depends on teachers, who will ultimately be responsible for translating policy into action and principles into practice in their interaction with students.

In order to realize educational objectives in Nigeria, there are well stated objectives on teacher education in the National Policy on Education as follow:

1. Produce highly motivated, conscientious and efficient classroom teachers for all levels of our educational system;

2. Encourage further the spirit of enquiry and creativity in teachers;

3. Help teachers to fit into the social life of the community and society at large and enhance their commitment to national goals;

* Corresponding Author E-Mail Address: dr_abayomi36@yahoo.com, abayomi.awe@fuoye.edu.ng 
4. Provide teachers with the intellectual and professional background adequate for their assignment and make them adaptable to changing situations; and

5. Enhance teachers' commitment to teaching profession.

The actualization of these objectives requires robust institutional frameworks for professional training programmes for practicing teachers. These institutional frameworks include: colleges of education, faculties of education, institutes of education, National Teachers' Institute and schools of education in the polytechnics among others. In spite of the existence of these institutional frameworks different categories of teachers have been identified as follow:

1. Those who are convinced that teaching is their calling and that they can best serve the country in that capacity.

2. Those who choose teaching and find satisfaction in it as compared with other professions.

3. Those who join the teaching profession from necessity rather than from choice.

4. Those with inadequate and poor academic records but who have had some secondary education

5. Those who have not been to secondary school because of their inability to pass the required entrance examination or because of lack of opportunity to do so in the past, (Afe, 2002|).

Baike cited in Olubor $(2011$, p. 70) pointed out that the teaching profession in Nigeria has over the years, acquired a character of its own. The profession is clouded with teachers with multifarious background, training and qualifications. Due to this situation, the high esteem enjoyed by the teacher in the past disappeared. Today's teacher lack finesse, panache and creativity. The situation is due to the fact that teacher lack motivation since most of them found themselves in the teaching profession because they could not secure prestigious jobs elsewhere.

Okebukola (2005) observed that some colleges of education offer admission to students with less than five credits. When these candidates enter colleges of education, they cannot meet up favourably in their studies. On graduation, they will move to faculties of education. He also identified another group of candidates admitted into faculties of education to read education as the last resort when all hopes have been lost in getting admission in the candidate's initial course of interest.

Audu and Egharevba (2016) observed that education is a course that most students are unwilling to apply for in Joint Admissions and Matriculation Board (JAMB) because of their negative perception about teaching. Most students admitted into the education faculties and colleges of education in Nigeria do not have interest in studying education because they do not have the intention of becoming teachers at the end of the programme. They only accepted to study education because they failed to get admission into their preferred courses. They see it as a stepping stone to other profession. Those in the colleges of education are there because they could not score the required marks in JAMB. Such students tend to have negative attitude towards teaching profession.

The working definition of the term "attitude" refers to an individual, who is passionate about teaching and views the teaching profession as an honorable and respected job, (Tok, 2011).Sudhaka and Reddy (2017) observed that the attitude of a teacher or any worker for that matter, towards his profession is an important aspect that helps one to feel well in his job. A favourable attitude towards teaching is likely to prove helpful to teachers in maintaining harmonious relations with other pupil, characterized by mutual affection and sympathetic understanding.

According to Bhargava\&Pathy (2014), attitude is the precursor of behaviour and varies from favourable to unfavourable through neutral. Attitude is made up of three components affective, behavioural and cognitive hence acts as a yardstick of the individual behaviour. 
The significance of positive attitude towards a given profession is described by Celikoz \& Cetin (2004). According to them, development of positive attitude towards profession helps in developing creative thinking and motivating students.

Srilatha (2017) observed that students enter the teacher training programme with already established beliefs but pre-service teacher training programmes help in shaping the attitude of teacher trainees by providing a series of experiences incorporated into their curriculum. A positive attitude towards teaching profession can bring the desired quality in the education sector by developing a sense of duty, professional competence and by giving them an insight of the students' needs and problems. Any educational programme that fails to bring favourable attitude in the student teachers towards teaching profession is no more an educational programme.

Anatasi, Celikoz and Cetin (2004) opined that the prospective teachers' attitude which is shaped in the teacher education programmes should be arranged in order to obtain a positive attitude for teaching profession. Srilatha (2017) observed that teacher educational programmes are considered to be attitude development programmes among the prospective teachers besides building competencies required for the teaching profession. Positive attitude towards profession helps for developing creative thinking and motivating students (Celikoz\& Cetin; 2004).

Apart from the general attitude towards teaching, there are other variables that affect teachers' attitude. For instance, Akkaya (2009) stated that gender factors affect the preservice teacher's attitude towards teaching profession. It was revealed that female pre-service teachers who are in Turkish EducationDepartment are more successful than male preserviceteachers with respect to their attitudes and academic success. Çapri and Çelikkaleli(2008) in their study indicated that femaleshad more positive attitudes.Gürbüz and Kişoğlu (2007) observed that the attitudes of pre-service teachers showed a statistically significant difference in terms of gender variable favoring females.Bozagan, Aydin and Yildrim (2007) revealed that the pre-service teacher's attitude towards teaching profession changes according to the gender and type of programme they graduated from.

Anikweze, Ojo and Maiyanga (2002) observed that no school leaver in Nigeria wants to be a teacher in view of the fact that teacher in Nigeria have been terribly and economically pauperized and emasculated. The word teacher and its related terms to the public signify abject poverty, inferiority and social misfit (Okemakinde 2013). Therefore, it would be interesting to examine the disposition of student teachers in training towards teaching profession. This is because their current disposition towards the profession, ultimately determines their commitment after graduation. Examination of potential teachers' attitude towards teaching profession could contribute to development of an enduring policy that could engender positive disposition of education undergraduate students towards teaching profession. It is in the light of the foregoing that this study is conducted.

\section{Purpose of the Study}

The emphasis on training of teaching personnel is considered crucial towards the realization of aims and objectives of education in any nation. However, the disposition of potential teachers in training towards teaching profession has implication on the quality of education. Therefore, the study investigated the perception of undergraduate education students at the Federal University Oye Ekiti towards teaching profession. In addition, it examined whether the variables of gender, entry qualifications, course level and age have any influence on undergraduate education students' attitude towards profession.

\subsection{Research Question}

In order to guide this study, one research question was generated: 
Research Question 1: What is the perception of undergraduate education students towards teaching profession?

\subsection{Hypotheses}

Based on the research questions four research hypotheses were formulated:

Hypothesis 1: There is no significant difference in the perception of female and male undergraduate students towards teaching profession.

Hypothesis 2: There is no significant difference in the perception of undergraduate students based on course level.

Hypothesis 3: There is no significant difference between the perception of young and old undergraduate students towards teaching profession

Hypothesis 4: There is no significant difference in the undergraduate students towards teaching profession based on entry qualification.

\section{Methodology}

The study used descriptive statistics of the survey type. The population of the study comprised of all undergraduate education students at the Federal University. OyeEkiti. The study sample comprised of 189 undergraduate education students at 200 level selected through random sampling technique. The instrument used for data collection was an adaptation of an instrument developed by Alkhateeb (2013). The questionnaire was tagged "Students' Attitude on Teaching Profession Questionnaire" (SATPQ)". The instrument comprises of 31 items that solicit for undergraduate education students "responses on teaching profession. The reliability of SATPQ was determined by test-retest method. This was done by administering the instrument on 20 undergraduate education students selected from Ekiti State University twice within two weeks interval. The scores obtained were correlated through Pearson Moment Correlation Method. A correlation coeffient of 0.80 obtained was adjudged as adequate for the instrument. The data collected were analysed using descriptive statistics such as frequency, meanwhile t-test was used as inferential statistic.

\section{Results}

The analysis of data and its interpretation are in two stages. Stage one involves analysis of general questions and stage two entails testing of hypotheses. A four-point scale was used for analysis. For instance, "Strongly Agree", "Agree" "Disagree" and "Strongly Disagree" were allotted 4, 3, 2 points and 1 point respectively. Following this, the mean scores were determined to take a decision. To take a decision, any mean score less than 2.5 was taken as 'Negative Attitude' while mean scores of 2.5and above was taken as 'Positive Attitude'. Discussion of the findings is presented at the end of each Table.

\subsection{Research Question}

What is the perception of undergraduate education students towards teaching profession?

Table 1.

Perception of undergraduate education students towards teaching profession

\begin{tabular}{clccccc}
\hline S/N & \multicolumn{1}{c}{ ITEMS } & SA & A & D & SD & MEAN \\
\hline 1 & It has always been my ambition to become a teacher & $32(17.8)$ & $53(29.4)$ & $44(24.4)$ & $51(28.3)$ & 2.37 \\
$2^{*}$ & The teaching profession is appropriate for me & $32(17.8)$ & $26(14.4)$ & $49(27.2)$ & $18(10.0)$ & 2.71 \\
$3^{*}$ & The teaching profession is an exciting profession & $64(35.6)$ & $82(45.6)$ & $26(14.4)$ & $8(4.4)$ & 3.12 \\
4 & $\begin{array}{l}\text { If I had to choose a profession again, I would choose } \\
\text { teaching }\end{array}$ & $29(16.1)$ & $40(22.2)$ & $58(32.2)$ & $5329.4)$ & 2.25 \\
5 & $\begin{array}{l}\text { Education was my first choice while seeking for } \\
\text { admission into university }\end{array}$ & $26(14.4)$ & $27(15.0$ & $57(31.7)$ & $70(38.9)$ & 2.05 \\
\hline
\end{tabular}




\begin{tabular}{|c|c|c|c|c|c|c|}
\hline $\mathbf{S} / \mathbf{N}$ & ITEMS & $\mathbf{S A}$ & $\mathbf{A}$ & $\mathbf{D}$ & SD & MEAN \\
\hline $6^{*}$ & I was not influenced to study education in this university & $46(25.6)$ & $76(42.2)$ & $37(20.6)$ & $21(11.7)$ & 2.82 \\
\hline $7^{*}$ & $\begin{array}{l}\text { I don't have any regret choosing education as my field of } \\
\text { study }\end{array}$ & $64(35.6)$ & $70(38.9)$ & $32(17.8)$ & $14(7.8)$ & 3.02 \\
\hline 8 & Teaching profession suits my life style & $37(20.6)$ & $49(27.2)$ & $57(31.7)$ & $37(20.6)$ & 2.48 \\
\hline $9^{*}$ & I believe I have special talent for teaching & $47(26.1)$ & $57(31.7)$ & 43(23.9) & $33(18.3)$ & 2.66 \\
\hline $10^{*}$ & Teaching profession will make me a fulfilled person & $50(27.8)$ & $70(38.9)$ & $38(21.1)$ & $22(12.2)$ & 2.82 \\
\hline $11^{*}$ & $\begin{array}{l}\text { Teaching profession will make me realise my full } \\
\text { potentials }\end{array}$ & $42(23.3)$ & $75(41.7)$ & $34(18.9)$ & $29(16.1)$ & 2.72 \\
\hline 12 & It makes me feel happy to think I will become a teacher & $27(15.0)$ & $68(37.8)$ & $49(27.2)$ & $36(20.0)$ & 2.48 \\
\hline 13 & I will allow my children to become teachers & $21(11.7)$ & $45(25.0)$ & $51(28.3)$ & $63(35.0)$ & 2.13 \\
\hline $14^{*}$ & Teaching is a well-recognized profession in the society & $85(47.2)$ & $58(32.2)$ & $25(13.9)$ & $12(6.7)$ & 3.20 \\
\hline $15^{*}$ & Teaching profession bring high esteem & $66(36.7)$ & $71(39.4)$ & $29(16.1)$ & $14(7.8)$ & 3.05 \\
\hline $16^{*}$ & Teaching brings about respect & $72(40.0)$ & $80(44.4)$ & $18(10.0)$ & $10(5.6)$ & 3.19 \\
\hline $17^{*}$ & Teaching is not inferior to any other profession & $51(28.3)$ & $71(39.4)$ & $42(23.3)$ & $16(8.9)$ & 2.87 \\
\hline $18^{*}$ & $\begin{array}{l}\text { Teaching profession brings good financial returns like } \\
\text { other professions }\end{array}$ & $38(21.1)$ & $58(32.2)$ & $47(26.1)$ & $37(20.6)$ & 2.54 \\
\hline $19^{*}$ & I can fulfil my financial obligations as a teacher & 4 & 61 & 47 & 28 & 2.67 \\
\hline $20^{*}$ & an education student & 68( & $72(40.0)$ & $25(13.9)$ & $15(8.3)$ & 3.07 \\
\hline $21^{*}$ & I don't feel inferior as an education student & $63(35.0)$ & $69(38.3)$ & $36(20.0)$ & $12(6.7)$ & 3.02 \\
\hline $22^{*}$ & ession will bring recognition $\mathrm{t}$ & & $73(40.6)$ & $43(23.9)$ & 15( & 2.87 \\
\hline $23^{*}$ & s any other profession & & & & $20(11.1)$ & 2.83 \\
\hline $24^{*}$ & Teaching requires specialised dills & $69(38.3)$ & $75(41.7)$ & $24(13.3)$ & $12(6.7)$ & 3.12 \\
\hline $25^{*}$ & $\begin{array}{l}\text { Teaching helps a person to be more influential in the } \\
\text { society }\end{array}$ & $68(37$. & 4.4) & $0.6)$ & $13(7.2)$ & 3.03 \\
\hline $26^{*}$ & Teaching as a profession has a bright future & $82(45.6)$ & 7.2) & 1) & 1) & 3.22 \\
\hline $27^{*}$ & e respected in the society & $66(36.7)$ & $65(36.1)$ & $35(19.4)$ & $14(7.8)$ & 3.02 \\
\hline $28^{*}$ & No reputation is better than teaching & $43(23.9)$ & $57(31.7)$ & $53(29.4)$ & $27(15.0)$ & 3.64 \\
\hline 29 & Teaching is not a stepping stone to other profession & $37(20.6)$ & $54(30.0)$ & $43(23.9)$ & $46(25.6)$ & 2.46 \\
\hline $30^{*}$ & Students enter into teaching profession as a last resort & $49(27.2)$ & $66(36.7)$ & $37(20.6)$ & $28(15.6)$ & 2.76 \\
\hline $31^{*}$ & rofession is sufficiently rewarded & $43(23.9)$ & $69(38.3)$ & $37(20.6)$ & $31(17.2)$ & 2.69 \\
\hline 32 & Teaching profession is sufficiently attractive to students & $32(17.8)$ & $56(31.1)$ & $51(28.3)$ & $41(22.8)$ & 2.44 \\
\hline $33^{*}$ & I do not feel ashamed as a prospective teacher & $54(30.0)$ & $81(45.0)$ & $29(16.1)$ & $16(8.9)$ & 2.96 \\
\hline
\end{tabular}

*='Item means above the cut-off point', Percentage responses are enclosed in parentheses.

Table 1 presents the perception of undergraduate education students towards teaching profession. Using a cutoff mean score of 2.50 for the rating scale, all the items had mean scores above the cutoff point except items 1, 4, 5, 8, 12, 13, 29 and 32. This implies that undergraduate education students have favourable perception towards teaching profession.

\subsection{Testing of Hypotheses}

\subsubsection{Hypothesis 1}

There is no significant difference in the perception of female and male undergraduate students towards teaching profession.

Table 2.

t-test showing undergraduate students' perception towards teaching profession by gender

\begin{tabular}{ccccccc}
\hline Gender & N & Mean & SD & df & t & p \\
\hline Male & 64 & 91.03 & 18.411 & 178 & 0.126 & 0.899 \\
Female & 116 & 91.38 & 17.26 & & & \\
\hline p $>0.05$ & & & & & &
\end{tabular}

Table 2 indicates that the calculated t-value is 0.126 with degree of freedom of 178 calculated at level of significance 0.05 . Since the calculated sig (0.899) is greater than the critical sig (0.05); the hypothesis is hereby not rejected. This implies that there is no significant difference in the perception of female and male undergraduate students towards teaching profession. 


\subsubsection{Hypothesis 2}

There is no significant difference in the perception of undergraduate students based on course level.

Table 3.

ANOVA showing perception of undergraduate students based on course level

\begin{tabular}{lccccc}
\hline Source & SS & df & MS & F & p \\
\hline Between Groups & 514.592 & 2 & 257.296 & .827 & .439 \\
Within Groups & 55071.653 & 177 & 311.139 & & \\
Total & 55586.244 & 179 & & & \\
\hline
\end{tabular}

$\mathrm{p}>0.05$

Table 3 indicates that the calculated F-value is 0.827 with degrees of freedom of 2 and 177 calculated at level of significance 0.05 , since the calculated sig $(0.439)$ is greater than the critical sig (0.05); the hypothesis is hereby not rejected. This implies that there is no significant difference in the perception of undergraduate students based on course level.

\subsubsection{Hypothesis 3}

There is no significant difference between the perception of young and old undergraduate students towards teaching profession.

Table 4.

$\mathrm{t}$-test showing undergraduate students' perception towards teaching profession by age

\begin{tabular}{ccccccc}
\hline Age & N & Mean & SD & df & t & p \\
\hline Young (Below 21years) & 11 & 90.64 & 17.99 & & & \\
Old (21years and above) & 68 & 92.27 & 17.09 & & 0.598 & 0.551 \\
\hline $\mathrm{p}>0.05$ & & & & & & \\
\hline
\end{tabular}

Table 4 indicates that the calculated t-value is 0.598 with degree of freedom of 178 calculated at level of significance 0.05 . Since the calculated sig (0.551) is greater than the critical sig (0.05); the hypothesis is hereby not rejected. This implies that there is no significant difference between the perception of young and old undergraduate students towards teaching profession.

\subsubsection{Hypothesis 4}

There is no significant difference in the undergraduate students towards teaching profession based on entry qualification.

Table 5.

ANOVA showing undergraduate students' perception towards teaching profession by entry qualification

\begin{tabular}{lccccc}
\hline Source & SS & df & MS & F & p \\
\hline Between Groups & 495.742 & 2 & 247.871 & .796 & .453 \\
Within Groups & 55090.502 & 177 & 311.246 & & \\
Total & 55586.2442 & 179 & & & \\
\hline p $>0.05$
\end{tabular}

$\mathrm{p}>0.05$

Table 5 indicates that the calculated F-value is 0.796 with degrees of freedom of 2 and 177 calculated at level of significance 0.05 , since the calculated $\operatorname{sig}(0.453)$ is greater than the critical sig (0.05); the hypothesis is hereby not rejected. This implies that there is no 
significant difference in the undergraduate students towards teaching profession based on entry qualification.

\section{Discussion}

In general, the results of the study indicated that undergraduate education students at the Federal University OyeEkiti had favourable perception towards teaching profession. This is premised on the fact that 25 out of the 33 items had mean scores at above average. However, when the items are analysed the remaining 8 items with mean scores below 2.5 constitute area of concern. For instance, Items 1, 4, 5 and 13 revealed that the students had negative perception about teaching profession. Item 1 that states: It has always been my ambition to become a teacher had a mean score of 2.37. This indicates that it was never the intention of these students to read education. This corroborates Okebukola (2005) who identified another category of candidates admitted into faculties of education to read education as the last resort when all hopes have been lost in getting admission in the candidate's initial course of interest. Item 4 which reads: If I had to choose a profession again, I would choose teaching profession has a mean score of 2.25. This implies that some of the respondents do not like teaching profession. Item 5 that reads: Education was my first choice while seeking for admission into the university had a mean score of 2.05 which implies that education was not the original course that the students applied for. Item 13 that reads: I will allow my children to become a teacher had a mean score of 2.13 .

The study also revealed that there was no significant difference in the perception of male and female undergraduates towards teaching profession. This finding does not support Akkaya (2009); Capri and Celikkhaleli and Gurbuz and Kisoglu (2007) that observed a significant difference between the perception of male and female undergraduate education students towards teaching profession.

The result of the study also showed that there was no significant difference in the perception of undergraduate education students towards teaching profession based on their course level. This finding also disagreed with Bozagam, Aydin and Yildrin (2007) that revealed that preservice teacher's attitude towards teaching profession changes according to the type of programme of study.

The result also indicated that age was not a factor in the perception of undergraduate students at the Federal University of OyeEkiti towards teaching profession. In addition, entry qualification had no influence on undergraduate students' perception towards teaching profession.

\section{Conclusion}

This study revealed that undergraduate education students at the Federal University OyeEkiti had positive perception towards teaching profession. However, when all the items in the Questionnaire were analysed one by one, it was observed that mean scores in some of the items indicated negative perception towards teaching profession among undergraduate education students at the Federal University OyeEkiti. Thus, it means the overall impression of a positive perception of undergraduate education students might not be a true reflection of students' perception.

\subsection{Recommendations}

Based on the outcome of the study the following recommendations were made:

1. Undergraduate education students must be provided with free education during the course of their studies.

2. Teaching as a profession must be accorded the necessary recognition by the government at all levels to make it attractive for undergraduate students. 
3. The condition of service of teachers must be improved to attract young education graduates to go into teaching profession and retain the ones already in the profession.

4. Automatic employment opportunities must be provided for graduates from the universities.

5. Universities must ensure that education programmes must not be regarded as alternative programme for those who are unable to secure admission to programmes of their first choice.

\section{References}

Akkhateeb, H.M (2013). Attitudes Towards Teaching Profession of Education students in Qatar, Innovative Teaching, 2(9).

Anikwese, C.M., Ojo, O.M., \& Aiyanga, A.A (2002). Teacher education in Nigeria: A Reflection of Kabiru Isiaku, Abuja, National Commission in Colleges of Education.

Bazdogan, A.E., Aydin D. \&Yildirim, K. (2007). Teachers' attitude towards teaching profession. Kirsehir Journal of Education. 8(2) 83-97

Bhargava, A., \&Pathy M.K. (2014). Attitude of Student Teachers Towards Teaching Profession, Turkish Online Journal of Distance Education 15 (3): 27-36

Capa Y \&Cil, N. (2000). Teachers' Attitudes towards Teaching Profession: An Investigation of the different variables. HaceHepe University Journal of Education., 18: 69-73

Capri, B and Celikkaleli, O. (2008). Investigating pre-service teachers' attitude toward teaching and professional self-efficacy belief according to their gender, programs and faculties. Inonu Universitesi Egitim Fakultesi Dergisi 9(15), 33-53

Celikoz, N. \& Cetin, F. (2004). Anatolian teacher high students' attitudes about the factors affecting the teaching profession. National Educational Journal, (162)

Egwu, S.O (2015). Attitude of Students towards Teaching Profession Nigeria: Implication for Education Development, Journal of Education and Practice, 6(20), pp 21-25

Gurbuz, H \& kisoglu, M. (2007). Attitude of the science and art faculty students and education faculty students and the non-thesis graduated education programme toward teaching profession (Atatink University Sample). Erzincan Esitim Fakultesi Dergisi 9(2), $71-83$

Kaya, A., \& Buyukkasap, E. (2005). Physics student teachers' profiles, attitude and anxiety toward teaching profession: An Erzurum sample kastamona Education Journal, 13(2), 367-380

Okemakinde, T. (2013). The place of teacher in national development. The European Journal of Humanities and Social Development in Nigeria 19(963-980)

Richardson, V. (2003). Pre-service teachers' belief: I. J, Raths \& A. C. McAninch (Eds.), Teacher belief and classroom performance: the impact of teacher education, Greennich, CT: Information Age publishing, Pp. 1-22

Srilatha, G. (2017). Differential Attitude of Student Teachers Towards Teaching Profession, International Journal of scientific Research and Education, 5(11) Pp 7732-7738

Tok, S. (2011). Pre-service primary education teachers' changing attitudes towards teaching: a longitudinal study. European Journal of Teachers Education, 34(1), 81-97 